\title{
Gastrochilus platycalcaratus (Rolfe) Schltr. (Orchidaceae: Epidendroideae: Vandeae: Aeridinae) - a new record for India
}

\author{
Khyanjeet Gogoi ${ }^{1}$, Koj Rinya ${ }^{2}$ and Sontosh Kumar Reddy ${ }^{3}$ \\ ${ }^{1}$ Communicating author: TOSEHIM, Regional Orchids Germplasm Conservation \& Propagation Centre \\ (Assam Circle), Daisa Bordoloi Nagar, Talap, Tinsukia 786 156, Assam, India \\ E-mail:khyanjeetgogoi@gmail.com \\ ${ }^{2,3}$ Divisional Forest Office, Hapoli Forest Division, Lower Subansiri District, \\ Arunachal Pradesh, India
}

[Received 12.11.2019; Revised 11.12.2019; Accepted 13.12.2019; Published 31.12.2019]

\begin{abstract}
A monopodial orchid viz. Gastrochilus platycalcaratus (Rolfe) Schltr. has been added to the orchid flora of India from the Ziro valley of Arunachal Pradesh, India. Adetailed description and a plate of colour illustrations of plant habit and floral parts have been provided.
\end{abstract}

Keywords: Orchidaceae, Gastrochilus platycalcaratus, new record, Arunachal Pradesh, India

\section{INTRODUCTION}

During a field trip under Orchid translocation project, to the forested area of Ziro Valley of Lower Subansiri district of Arunachal Pradesh, India on $20^{\text {th }}$ September 2019, the authors collected an unidentified epiphytic orchid in its vegetative condition with flower buds. The orchid was planted at the orchid trail located in the Talle Wildlife Sanctuary at Ziro valley of Arunachal Pradesh where it flowered under observation in October 2019. On the basis of available literature (King \& Pantling 1898; Pradhan 1979; Chowdhery 1998; Pearce \&Cribb 2002; Lucksom 2007; Chen et al. 2009; Rao 2009, 2010; Swami 2017; Gogoi 2018) and critical examination of the flowers, it was identified as Gastrochilus platycalcaratus (Rolfe) Schltr. which is known so far only from China (S.Yunnan), Myanmar and Thailand. Hence, the present report of its occurrence from Arunachal Pradesh forms a new distributional record to India. A detailed description, illustration, information on habitat and distribution of the taxon are provided in the present communication to facilitate the field botanists to locate it in other parts of North-eastern India. The voucher specimen has been deposited at the ASSAM Herbarium of the Botanical Survey of India at shillong and Herbarium of The Orchid Society of Eastern Himalaya (TOSEHIM), Regional Orchid Germplasm Conservation and Propagation Centre (Assam Circle), Assam.

Gastrochilus D. Don is a monopodial orchid genus comprising of ca. 65 species widely distributed around E, SE and S Asia (Pridgeon et al. 2014; Govaerts et al. 2018; Liu \& Gao 2018). This genus is remarkable in the predominantly tropical subtribe Aeridinae (Pridgeon et al. 2014) by its high species richness in East Asia and in the Himalayas (Tsi 1996). So far, 19 species have been estimated from India (Misra 2007) of which 12 species (including 1 variety) viz. Gastrochilus acutifolius (Lindl.) Kuntze, G. affinis (King \&Pantl.) Schltr., G. arunachalensis Nageswara Rao, G. bigibbus (Rchb.f. ex Hook.f.) Kuntze, G. calceolaris (Sm.) D.Don, Gastrochlus dasypogon (Buch.-Ham. ex Sm.) Kuntze, G. distichus (Lind1.) Kuntze, G. intermedius (Griff. ex Lindl.) Kuntze, G. obliquus (Lindl.) Kuntze, G. obliquus 


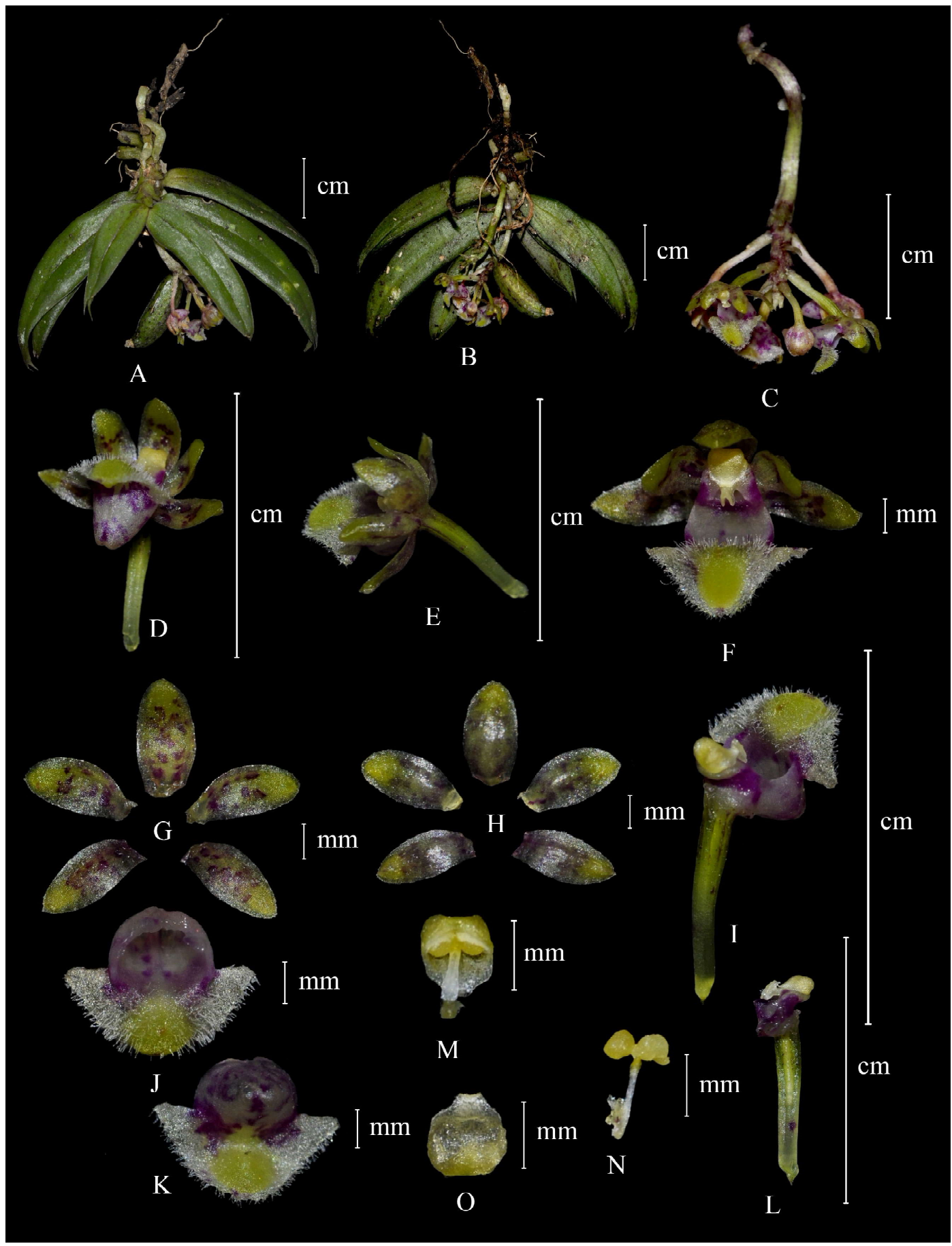

PLATE - I. Gastrochilus platycalcaratus (Rolfe) Schlechter: A \& B. Habit; C. Inflorescence; D, E \& F. Different views of flower; G \& H. Perigone, ventral and dorsal views; I. Lip with ovary and column; J \& K. Lip; L. Pedicel, ovary and column; M. Anther cap with Pollinarium in situ; N. Anther; O. Anther cap. 
var. suavis (Seidenf.) Tsi., G. rutilans Seidenf. and G. sessanicus Nageswara Rao are found in Arunachal Pradesh (Hegde 2017). With the present collection of Gastrochilus platycalcaratus (Rolfe) Schlechter from the Ziro Valley of Arunachal Pradesh, the total number of species of this genus in India and Arunachal Pradesh increases up to 20 and 13 respectively.

Gastrochilus platycalcaratus (Rolfe) Schltr., Orchideen Beschreib. Kult. Zücht.: 582.1909.

Saccolabium platycalcaratum Rolfe, Bull. Misc. Inform. Kew 1909: 368. 1909; Gastrochilus diannanensis Z.H. Tsi \& Y.Z. Ma. [PLATE - I]

Plants 5-7 cm. Leaves 3-6, nearly basal, green, tinged with purple, oblong, 3-5 $\times 0.7-1.2$ $\mathrm{cm}$, obtuse, unequally bilobed. Inflorescence racemose, many-flowered; peduncle pale yellowish green, usually $2-3 \mathrm{~cm}$; rachis $0.5 \mathrm{~cm}$; floral bracts ovate-triangular, obtuse; pedicel and ovary yellowish green with purple spots, $0.8 \mathrm{~cm}$. Flowers widely opening; sepals and petals yellowish green, sometimes with purplish red spots; lip whitish, with purple-blackish spots on hypochile and greenish cushion on epichile. Dorsal sepal oblong, concave, $0.3 \times$ $0.2 \mathrm{~cm}$, apex obtuse; lateral sepals slightly oblique, oblong, $0.3 \times 0.1 \mathrm{~cm}$, apex obtuse. Petals ovate-elliptic, $0.3 \times 0.2 \mathrm{~cm}$, apex obtuse; lip with an epichile and a hypochile; epichile triangularovate, $0.3 \times 0.3 \mathrm{~cm}$, adaxially densely hirsute and with a central cushion, slightly reflexed, rounded at apex; hypochile subconic, slightly narrowed at middle, strongly dorsiventrally compressed from middle to tip, subtruncate and concave at tip. Column pale yellow, tinged with purplish blue, short; anther cap yellow.

Specimen Cited: INDIA, Arunachal Pradesh, Zero Valley, Gogoi 00805; dated October 15, 2019 (ASSAM, TOSEHIM).

Flowering \& Fruiting: September - October.

Habitat: On tree trunks in coniferous forests.

General distribution: India (Ziro, Arunachal Pradesh), southern Yunnan of China, Myanmar and Thailand.

Status: Unknown.

\section{Acknowledgements}

The authors are grateful to Dr. Pankaj Kumara, Kadoorie Farm and Botanic Garden (KFBG) Corporation, Lam Kam Road, Tai Po, New Territories, Hong Kong S.A.R., China for providing literature and valuable suggestion regarding the identity of the plant. The authors are also thankful to the Department of Environment and Forest, Government of Arunachal Pradesh (India) for their cooperation during the entire survey.

\section{LITERATURE CITED}

Chen, X.; Liu, Z.; Zhu, G.; Lang, K.; Ji, Z.; Luo, Y.; Jin, X.; Cribb, P.J.; Wood, J.J.; Gale, S.W.; Ormerod, P.; Vermeulen, J.J.; Wood, H.P.; Clayton, D. \& Bell, A. 2009. Orchidaceae, in: Wu, Z.; Raven, P.H. \& Hong, D. (eds), Flora of China. Vol. 25. Science Press, Beijing; Missouri Botanical Garden Press, St. Louis, USA

Chowdhery, H.J. 1998. Orchid Flora of Arunachal Pradesh. Bishen Singh Mahendra Pal Singh, Dehra Dun, India.

Gogoi, K. 2018. Wild Orchids of Assam - A Pictorial Guide. Assam State Biodiversity Board, Guwahati, Assam.

Govaerts, R.; Bernet, P.; Kratochvil, K.; Gerlach,G.; Carr, G.; Alrich, P.; Pridgeon, A.M.; Pfahl, J.; Campacci, M.A.; Holland Baptista, D.; Tigges, H.; Shaw, J.; Cribb, P.J.; 
George, A.; Kreuz, K. \& Wood, J. 2018. World checklist of Orchidaceae. The Board of Trustees of the Royal Botanic Gardens, Kew. Available from: http:// apps.kew.org/wcsp/monocots/ [accessed 17 October 2019]

King, G. \& Pantling, R, 1898. The orchids of the Sikkim Himalayas. Annals of the Royal Botanical Garden Calcutta 8: 1 - 342.

Liu, Q. and Gao, J.Y. 2018. Gastrochilus dulongjiangensis (Aeridinae, Vandeae, Epidendroideae, Orchidaceae), a new species from Yunnan Province, China. Phytotaxa 340(3): $293-296$.

Lucksom, S.Z. 2007. The Orchids of Sikkim and North East Himalaya. Development Area, Jiwan Thing Marg, Gangtok, East Sikkim, India.

Misra, S. 2007. Orchids of India. Bishen Singh Mahendra Pal Singh, Dehra Dun, India.

Pearce, N.R. \& Cribb, P.J. 2002. Orchids of Bhutan: Flora of Bhutan. Vol. 3, No. 3. Royal Botanical Garden, Edinburg.

Pedersen, H.A.E.; Kurzweil, H.; Suddee, S.; Vogel, Ed F.; Cribb, P. J.; Chantanaorrapint, S.; Watthana, S.; Gale, S.W.; Seelanan, T. \& Suwanphakdee, C. 2014. Flora of Thailand, Vol-12, 2: Prachachon co. 1td., Thailand.

Pradhan, U.C. 1979. Indian Orchids Guide to Identification and Culture. Vol- II. Thomson Prass, Faridabad, India.

Pridgeon, A.; Cribb, P.J.; Chase, M. \& Rasmussen, F.N. 2014. Genera orchidacearum, Epidendroideae (part three), vol. 6. Oxford University Press, Oxford, pp.188 - 191.

Rao, A.N. 2009. Monopodial orchids of Arunachal Pradesh (India) - Classification, Taxonomy Distribution and Conservation. Bull. Arunachal For. Res. 25 (1\&2): 55 - 92.

Rao, A.N. 2010. Orchid flora of Arunachal Pradesh - an update. Bull. Arunachal For. Res. 26 (1\&2): $82-110$.

Swami, N. 2017. Orchids of Ziro, Thomson Press India Ltd.

Tsi, Z. 1996. A preliminary revision of Gastrochilus (Orchidaceae). Guihaia 16: 123 - 154. 